\title{
TESTING FOR SARS-COV-2
}

\section{TESTIRANJE NA SARS-COV-2}

Dušan Popadić ${ }^{1}$

${ }^{1}$ Univerzitet u Beogradu, Medicinski fakultet, Institut za mikrobiologiju i imunologiju, Beograd, Srbija

Correspondence: dusan.popadic@med.bg.ac.rs

\section{Abstract}

Keywords:

COVID-19,

SARS-CoV-2, rtRT-PCR, antigen testing, rapid tests, T-cell response, database
This review article describes the principles and implications of certain tests for diagnosing SARS-CoV-2 infections. The advantages and disadvantages of certain tests, both those in routine diagnostic application and those that have primarily research significance, are discussed. Also, a review of the practice of reporting results is given, as well as recommendations for its improvement.

\section{Sažetak}

Ključne reči:

COVID-19,

SARS-CoV-2, rtRT-PCR, testiranje na antigen,

brzi testovi,

T-ćelijski odgovor, baza podataka
Popadić D. MedPodml 2021, 72(3):12-19

(C)

The authors declare no conflicts of interest.
U ovom preglednom članku su opisani izvođenje i značaj pojedinih testova za dijagnostikovanje SARS-CoV-2 infekcije. Obrađene su prednosti i nedostaci pojedinih testova, kako onih u rutinskoj dijagnostičkoj primeni, tako i onih koji imaju prevashodno istraživački značaj. Dat je i osvrt na praksu izveštavanja rezultata, kao i preporuke za njeno unapređenje. 
Uvod

Pandemija COVID-19, izazvana širenjem korona virusa SARS-CoV-2, sa više od sto sedamdeset sedam miliona zaraženih i više od tri miliona i osamsto pedeset hiljada preminulih, nanela je ogromnu štetu gotovo svim aspektima svakodnevnog života u savremenom ljudskom društvu (1). Novi zahtevi postavljeni pred dijagnostičke laboratorije višestruko su premašili postojeće tehničke, kadrovske i materijalne kapacitete. Osnova laboratorijske dijagnostike COVID-19 je Real-Time Reverse Transcription Polymerase Chain Reaction (rtRT-PCR), metod za detekciju prisustva SARS-CoV-2 genoma u materijalu uzetom od pacijenta. Dopuna rtRT-PCR testiranju su dokazivanje SARS-CoV-2 antigena u biološkom materijalu uzetom od pacijenta $i$, u novije vreme, utvrđivanje postojanja imunskog odgovora na SARS-CoV-2 u telesnim tečnostima osoba koje imaju aktivnu infekciju tim virusom ili su tu infekciju prebolele (2). Postupak laboratorijskog testiranja može da bude podeljen u nekoliko faza na sledeći način: 1) postavljanje indikacija za testiranje; 2) uzimanje materijala i uvođenje u evidenciju; 3 ) transport materijala do dijagnostičke laboratorije (što se ne primenjuje ukoliko se testiranje izvodi tzv. "point of care" testovima, PoC); 4) prijem i razvrstavanje materijala; 5) obrada uzoraka nakon prijema; 6) izvođenje testova; 7) saopštavanje rezultata i objavljivanje podataka. Pored toga, značajno je sagledavanje još nekih aspekata, neophodnih za sprovođenje testiranja, a koji se odnose na osoblje koje izvodi testove i nabavku lične zaštitne opreme i svih potrebnih materijala koji se koriste u testiranju.

\section{Postavljanje indikacija za testiranje}

Indikacije za testiranje mogu da budu medicinske i paramedicinske. Potrebno je da se testiraju osobe sa kliničkim simptomima i znacima akutne respiratorne infekcije, njihovi kontakti, medicinsko i nemedicinsko osoblje koje je bilo u kontaktu sa obolelima ili infektivnim materijalom i lekari. Osim tih osoba, u zavisnosti od epidemiološke procene, testiraju se državni i javni službenici i osobe koje dolaze iz zagraničnih žarišta infekcije. U poslednje vreme nameće se velika potreba za testiranjem osoba koje bi želele da putuju u zemlje čija administracija zahteva negativan rtRT-PCR rezultat za prelazak državne granice.

\section{Uzimanje materijala i uvođenje u evidenciju}

Iako deluje trivijalno, uzimanje materijala je važno kao i druge faze testiranja. Uzorkovanje se vrši na više stotina mesta u Srbiji i poslednjih meseci je u velikoj meri uniformisano, što je olakšalo postupke u laboratorijskom testiranju. Na mestu uzorkovanja unosi se jedinstveni matični broj pacijenta (ili evidencioni broj za stranog državljanina) u COVID-19 bazu, a sistem povlači generalije pacijenta iz dostupnih baza podataka. Zatim se priprema posuda sa nalivenim transportnim medijumom i zalepljenom nalepnicom koja na sebi ima odštampanu šestoznakovnu šifru i bar-kod. Skeniranjem bar-koda očitana šestoznakovna šifra pridružuje se imenu pacijenta u COVID-19 bazi, a zatim se opredeljuje u koju laboratoriju se uzorak šalje. Pri manuelnom unošenju šestoznakovne šifre često se prave greške, što otežava kasniju identifikaciju uzorka. To dovodi do velikih kašnjenja i otežava izdavanje validnih rezultata. Pogrešan odabir laboratorije u koju se uzorak upućuje takođe otežava, a ponekad u potpunosti onemogućuje pravovremenu identifikaciju i obradu uzorka.

Uzimanje uzoraka bi trebalo da se vrši pomoću brisa od dakrona, rejona ili viskoze na tankom plastičnom štapiću sa tačkom lomljenja na $45 \mathrm{~mm}$ od vrha brisa iz nazofarinksa (slika 1). Brisevi ždrela i nosa pomoću dva drvena štapića na koje je namotana pamučna vata nisu adekvatni i mogu da umanje osetljivost testa. Poznato je da drvo može da sadrži inhibitore enzimskih reakcija, a pamuk nije pogodan za Polymerase Chain Reaction (PCR) pretragu na viruse. Na kraju, nos i ždrelo nisu najpogodnija mesta za uzimanje materijala za dijagnostiku SARS-CoV-2, već je to nazofarinks. Idealno bi bilo da se virusni transportni medijum (VTM) 1,5 - $2 \mathrm{ml}$ sipa u posude nalik na Bijou kontejnere (zapremina 5 - $6 \mathrm{ml}$, visine oko $50 \mathrm{~mm}$ i unutrašnjeg prečnika oko $15 \mathrm{~mm}$ sa poklopcem koji dihtuje) jer obrada uzorka iz takvih posuda izrazito ubrzava proces dalje obrade. Korišćenje drugačijih posuda usporava dalje postupke obrade uzoraka. Dovoljno je reći da svako zaranjanje automatske pipete sa nastavkom u posudu čiji je zid viši od dužine nastavka nosi opasnost od kontaminacije pipete i zahteva njenu dekontaminaciju, što jako otežava rad i usporava proces dijagnostike.

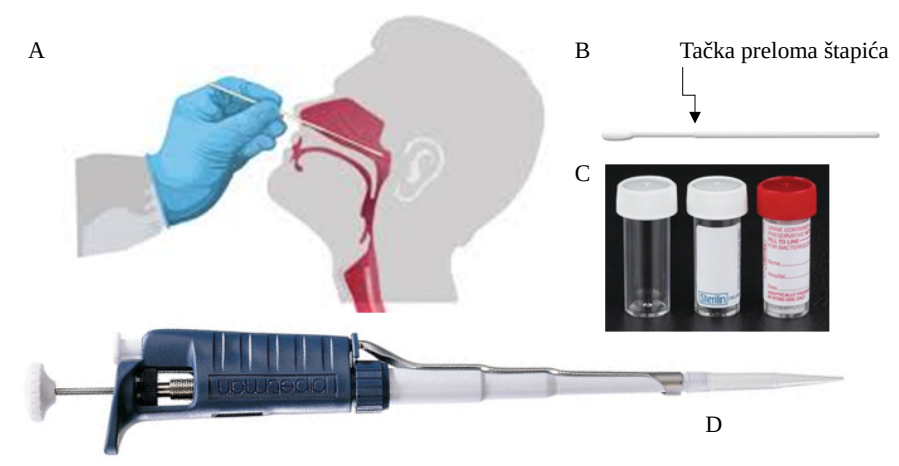

Slika 1. A. Pravilno uzorkovanje (bris nazofarinksa). B. Plastični štapić sa brisem od dakrona i tačkom preloma na $45 \mathrm{~mm}$ od vrha brisa. C. Bijou bočice (kontejneri). D. Standardni jednokratni nastavak za automatsku pipetu u približnoj razmeri sa veličinom Bijou bočica.

Uzorkovanje može da se vrši u prostoriji ili na otvorenom. Uzorkovanje na otvorenom prostoru je veoma praktično, ali nije moguće sprovođenje u svim vremenskim uslovima. Uzorkovanje u zatvorenim prostorijama može da se obavlja unutar zdravstvenih ustanova ili izvan njih, na terenu.

PoC testovi po pravilu imaju sav potrebni materijal za uzorkovanje i potrebno je samo da se prati uputstvo proizvođača. Ukoliko se radi o testovima za detekciju 
antigena biološki materijal se uzima brisom, slično kao za rtRT-PCR testiranje, a ukoliko se detektuju antitela uzima se uzorak kapilarne ili, ređe, venske krvi. Uzorkovanje i testiranje se obavljaju na istom mestu, tj. u istoj ustanovi.

Uzorak periferne krvi koji se koristi za dokazivanje prisustva antitela uzima se u epruvetu bez antikoagulansa ili sa dodatkom aktivatora koagulacije kako bi se dobio serum.

Uzorak periferne krvi koji se koristi za funkcionalno dokazivanje celularnog imunskog odgovora potrebno je izvaditi u epruvetu sa heparinom, koji sprečava koagulaciju krvi. Primena drugih antikoagulansa (npr. onih koji heliraju $\mathrm{Ca}^{2+}$ jone) onemogućava funkcionalni odgovor limfocita.

Transport materijala do dijagnostičke laboratorije

Nakon uzimanja brisa za rtRT-PCR i potapanja $\mathrm{u}$ transportni medijum uzorci se čuvaju u frižideru na $2-8^{\circ} \mathrm{C}$, a zatim šalju u laboratoriju, pri čemu je preporučeno vreme od momenta uzorkovanja do momenta obrade uzorka $<24 \mathrm{~h}$, a ne sme da prekorači $72 \mathrm{~h}$. Uzorci treba da budu propisno zatvoreni i da se transportuju u stalcima, sa složenim pratećim listama (ukoliko postoje), a obavezno sa listom svih uzoraka. Uzorci se transportuju na temperaturi od 2 do $8^{\circ} \mathrm{C}$, što se postiže pomoću ručnih frižidera. Prilikom transporta frižider sa uzorcima se učvršćuje tako da ne može da se prevrne tokom vožnje.

Uzorci za serološke analize se takođe transportuju na temperaturi od 2 do $8^{\circ} \mathrm{C}$, ali nije neophodno da se obrađuju u tako kratkom roku. Za čuvanje duže od mesec dana preporučuje se smrzavanje na $-70^{\circ} \mathrm{C}$ ili na $-20^{\circ} \mathrm{C}$ ukoliko nema uslova za duboko zamrzavanje.

Periferna krv koja se koristi za funkcionalno dokazivanje celularnog imunskog odgovora se ne rashlađuje već je potrebno da se uzorci na sobnoj temperaturi transportuju što je moguće ranije, a svakako za manje od $24 \mathrm{~h} \mathrm{u}$ laboratoriju.

Od preuzimanja do predaje uzoraka vozač je dužan da se pridržava svih mera lične zaštite.

\section{Prijem i razvrstavanje materijala}

Prijem i razvrstavanje su bitno promenjeni i unapređeni u odnosu na početak pandemije. Osnovna promena se ogleda u menjanju protokola, odnosno elektronskom registrovanju uzoraka. Izbačene su iz upotrebe knjige prijema i postupak se sveo na dodeljivanje broja laboratorijskog protokola (na posudu sa brisom) i pridruživanje laboratorijskog broja protokola šestoznakovnoj šifri u bazi podataka sa primljenim uzorcima. $\mathrm{U}$ automatizovanim laboratorijama (npr. laboratorija Vatreno oko, Beograd) šestoznakovna šifra bila je ujedno i broj laboratorijskog protokola. U nekim laboratorijama su uzorci i svi prateći materijali odmah po prispeću inaktivisani toplotom od 60 do $70^{\circ} \mathrm{C}$ u trajanju 45 - 60', a u drugima ne, u zavisnosti od vrste VTM koji je korišćen za uzorkovanje.
Primena PoC testova značajno pojednostavljuje procedure prijema i razvrstavanja materijala jer se izvode u istoj ustanovi u kojoj se vrši uzorkovanje i obično se radi sa malim brojem uzoraka. Isto se može reći i za testove za merenje funkcionalnog odgovora T-limfocita na stimulaciju antigenima SARS-CoV-2.

Detekcija antitela se radi rutinski u velikom broju laboratorija prema pravilima koja važe i za druge serološke analize. Pošto je broj laboratorija u kojima se vrši serološko testiranje relativno veliki, jasno je da u pojedinačne laboratorije ne dolazi preveliki broj uzoraka, tako da proces prijema i razvrstavanja materijala nije preterano zahtevan.

\section{Obrada uzoraka nakon prijema}

\section{rtRT-PCR}

Uzorci za rtRT-PCR mogu da se obrađuju na dva načina. To su liza sedimenta i ekstrakcija nukleinskih kiselina (NK) iz transportnog medijuma. Prednost metoda koje podrazumevaju lizu sedimenta je brzina izvođenja, a prednost ekstrakcije NK je veća čistoća uzorka. I liza sedimenta i ekstrakcija NK mogu da se izvode ručnim metodama, dok su automatske metode po pravilu rezervisane za ekstrakciju NK. Veoma je važno da se uzorci pre dalje obrade snažno promućkaju (poželjno na vorteksu) da bi se uzorak homogenizovao i oslobodili virusi sa brisa u transportni medijum.

$\mathrm{Na}$ brzinu obrade uzorka bitno utiče primenjena metodologija. Laboratorijski tehničar može da obradi oko tri stotine uzoraka za osam sati ukoliko se vrši liza. Potpuno automatizovani sistemi uz minimalno opterećenje tehničara mogu da ekstrahuju RNK iz više od šest stotina uzoraka za osam sati. Najmanja procesivnost je kada se vrši ručna ekstrakcija NK pomoću afinitetnih kolonica i tada je moguće obraditi do sto uzoraka tokom radnog vremena. Zajedničko svim tim metodama je to da zahtevaju značajno viši stepen obučenosti osoblja nego uobičajene laboratorijske procedure.

\section{Priprema uzoraka za izvođenje drugih testova}

Uzorci koji se analiziraju PoC testovima po pravilu se pripremaju jednostavno striktno prema uputstvu proizvođača testa. Kod uzoraka za serološka testiranja neophodno je centrifugiranje radi izdvajanja seruma, a zatim pravljenje odgovarajućih razblaženja seruma prema uputstvu proizvođača testa. Uzorci krvi za merenje funkcionalnog odgovora T-limfocita na stimulaciju antigenima SARSCoV-2 ne zahtevaju nikakvu obradu osim resuspendovanja istaloženih ćelija u krvnoj plazmi, što se postiže izvrtanjem epruvete gore-dole nekoliko puta.

\section{Izvođenje dijagnostičkih testova}

Različiti dijagnostički testovi zasnovani na različitoj metodologiji daju odgovore na različita pitanja i imaju svoje prednosti i nedostatke, od kojih su najvažniji navedeni u tabeli 1. 
Tabela 1. Najčešći testovi korišćeni u dijagnostici SARS-CoV-2 infekcije sa najvažnijim prednostima i nedostacima $(3,4)$.

\begin{tabular}{|c|c|c|c|}
\hline Metodologija & Detekcija & Prednost & Nedostatak \\
\hline rtRT-PCR & Genomska RNK virusa & $\begin{array}{c}\text { Visoka osetljivost i } \\
\text { specifičnost, velika } \\
\text { procesivnost, mogućnost } \\
\text { kvantifikacije }\end{array}$ & $\begin{array}{l}\text { Visoki troškovi testiranja, } \\
\text { potreba za dobro obučenim } \\
\text { kadrom }\end{array}$ \\
\hline $\begin{array}{l}\text { Imunohromatografija PoC } \\
\text { testovi za detekciju antigena }\end{array}$ & Antigeni virusa & $\begin{array}{c}\text { Niski troškovi, brzo izdavanje } \\
\text { rezultata }\end{array}$ & $\begin{array}{c}\text { Niža osetljivost u odnosu na } \\
\text { rtRT-PCR, nema mogućnosti } \\
\text { kvantifikacije }\end{array}$ \\
\hline $\begin{array}{l}\text { Imunohromatografija PoC } \\
\text { testovi za detekciju antitela }\end{array}$ & $\begin{array}{c}\text { Antitela specifična za virusne } \\
\text { antigene }\end{array}$ & $\begin{array}{c}\text { Niski troškovi, brzo izdavanje } \\
\text { rezultata }\end{array}$ & $\begin{array}{l}\text { Niža osetljivost u odnosu na } \\
\text { enzimske imunotestove ,nema } \\
\text { mogućnosti kvantifikacije }\end{array}$ \\
\hline Enzimski imunotestovi & $\begin{array}{c}\text { Antitela specifična za virusne } \\
\text { antigene }\end{array}$ & $\begin{array}{c}\text { Visoka osetljivost, velika } \\
\text { procesivnost, mogućnost } \\
\text { kvantifikacije }\end{array}$ & $\begin{array}{c}\text { Viši troškovi u odnosu na } \\
\text { PoC testove, nema direktne } \\
\text { korelacije sa koncentracijom } \\
\text { neutrališućih antitela }\end{array}$ \\
\hline Test neutralizacije virusa & $\begin{array}{l}\text { Neutrališuća antitela } \\
\text { specifična za } S \text { antigen }\end{array}$ & $\begin{array}{c}\text { Određivanje prisustva i } \\
\text { koncentracije najrelevantnijih } \\
\text { neutrališućih antitela }\end{array}$ & $\begin{array}{l}\text { Viši troškovi i niža } \\
\text { procesivnost u odnosu na } \\
\text { enzimske imunotestove }\end{array}$ \\
\hline Quantiferon SARS-CoV-2 & $\begin{array}{l}\text { Sekrecija interferona gama po } \\
\text { stimulaciji antigenima virusa }\end{array}$ & $\begin{array}{c}\text { Dokazivanje efektorskih } \\
\text { T-limfocita što može da } \\
\text { prethodi detekciji antitela, } \\
\text { velika procesivnost }\end{array}$ & $\begin{array}{c}\text { Istraživački, a ne dijagnostički } \\
\text { test }\end{array}$ \\
\hline $\begin{array}{l}\text { Test limfoblastne } \\
\text { transformacije }\end{array}$ & $\begin{array}{l}\text { Limfoblasti nastali nakon } \\
\text { stimulacije antigenima virusa }\end{array}$ & $\begin{array}{c}\text { Dokazivanje postojanja } \\
\text { specifičnih subpopulacija T- i } \\
\text { B-limfocita u perifernoj krvi } \\
\text { pacijenta }\end{array}$ & $\begin{array}{l}\text { Istraživački, a ne dijagnostički } \\
\text { test, mala procesivnost }\end{array}$ \\
\hline
\end{tabular}

\section{rtRT-PCR}

Izvođenje rtRT-PCR podrazumeva dva koraka. Prvi korak je reverzna transkripcija, a drugi PCR sa detekcijom PCR produkata u realnom vremenu (5). Primena enzimskog miksa koji u sebi sadrži reverznu transkriptazu i termostabilnu DNK i zavisnu DNK polimerazu omogućava da se te dve reakcije sukcesivno odigraju u jednoj reakcionoj smesi. Takve reakcione smese značajno smanjuju manuelni rad i mogućnost greške, kontaminaciju u radu i cenu testa. Test rtRT-PCR po pravilu traje oko 90 minuta, a u jednom bloku PCR mašine istovremeno se analizira do 94 uzorka. U Srbiji je bio dostupan veliki broj različitih testova (više od dvadeset) tom metodologijom. Reagensi

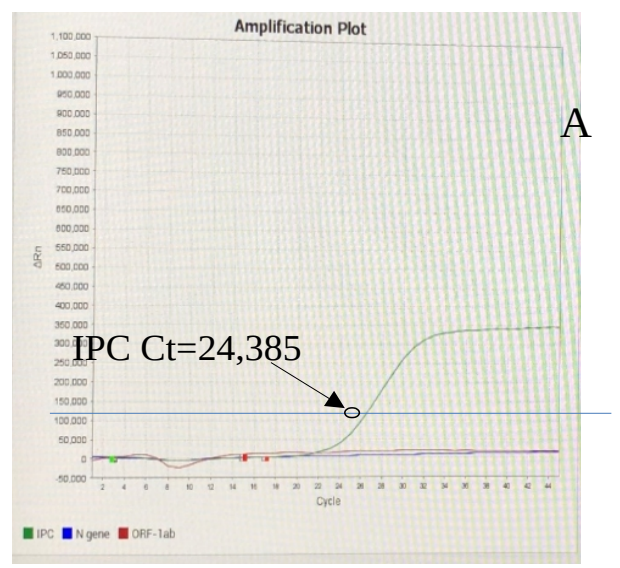

su u sebi sadržali oligonukleotide za amplifikovanje jedne ljudske sekvence (interna pozitivna kontrola reakcije, IPC) i jedne do tri virusne sekvence. Najveći broj testova je odrađen sa reagensima kompanija $B G I$ (IPC + jedan virusni gen), SanSure (IPC + dva virusna gena, slika 2) i GeneFinder (IPC + tri virusna gena). Interpretacija dobijenih rezultata je varirala tokom vremena, što je posledica primene različitih testova i promene kriterijuma za interpretaciju koje su povremeno ažurirali proizvođači testova.

\section{PoC testovi za dokazivanje antigena}

Testovi su namenjeni za brzu dijagnostiku infekcije i baziraju se na imunohromatografskim metodama za

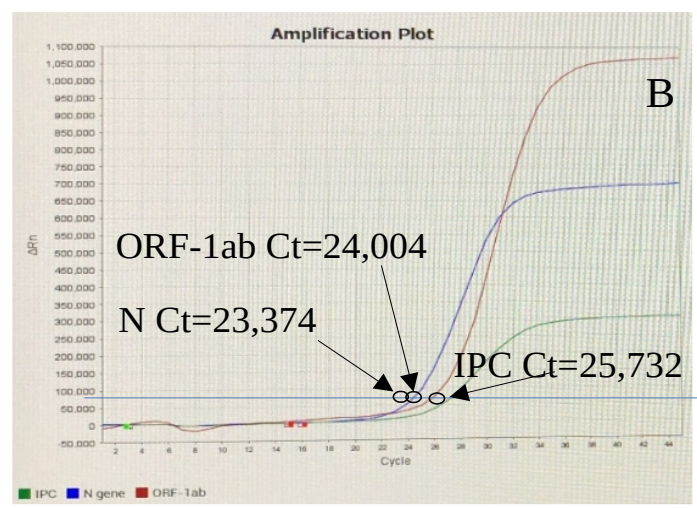

Slika 2. Krive amplifikacije virusnih gena (crveno i plavo) i IPC (zeleno) kod negativnog uzorka (A) i pozitivnog uzorka (B). 
dokazivanje različitih antigena SARS-CoV-2. Materijal se, po pravilu, uzima brisom, mada postoje i testovi u kojima se kao materijal koristi saliva (test koji je razvila Neomedika iz Niša). Takvi testovi su znatno jeftiniji, ali i manje osetljivi nego rtRT-PCR. Ukratko, uzorak koji se testira se potapa ili meša sa odgovarajućim puferom, nakon čega se pomoću pipete ili kapaljke nanosi u otvor na test kaseti ili test strip koji je predviđen za nanošenje uzorka. Nakon 10 - 15 minuta, u zavisnosti od uputstva koje je dostavio proizvođač testa, rezultat se očitava u otvoru za očitavanje rezultata (slika 3). Rezultati dobijeni takvim testom su u potpunosti kvalitativni. Pozitivan test znači da osoba u svom organizmu ima virus, odnosno u najmanju ruku virusne antigene i da je potencijalno infektivna. Vakcinacija ne može da učini rezultat testa pozitivnim.

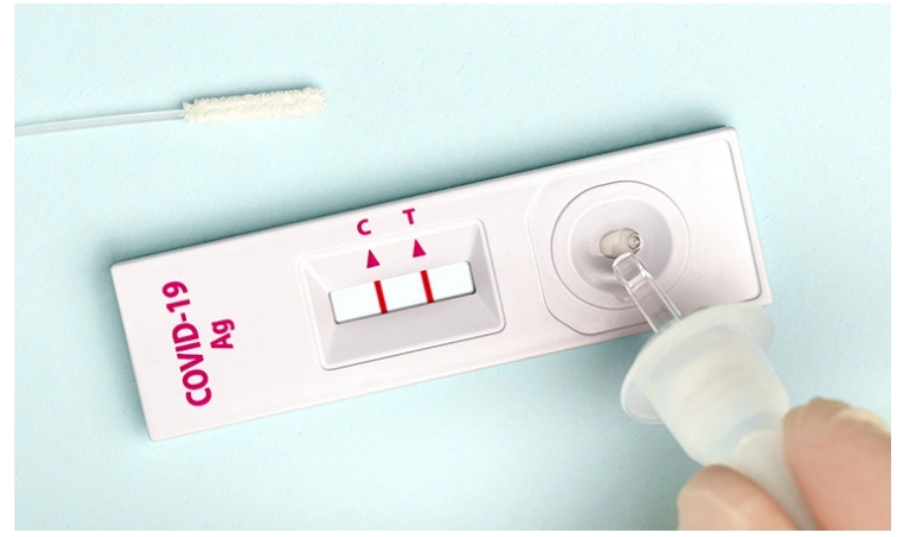

Slika 3. Test kaseta sa pozitivnim rezultatom na SARS-CoV-2 antigen.

\section{PoC testovi za dokazivanje antitela}

Testovi su namenjeni za brzu dijagnostiku postojanja humoralnog imunskog odgovora na antigene SARS-CoV-2. Baziraju se na imunohromatografskim metodama za dokazivanje različitih antitela (po pravilu IgM, IgG ili IgA) na pojedine antigene SARS-CoV-2. Krv se, po pravilu, uzima iz vene, mada postoje i testovi u kojima se kao materijal koristi kapilarna krv. Takvi testovi su znatno jeftiniji, ali i manje osetljivi nego enzimski imunotestovi. Ukratko, uzorak koji se testira meša se sa odgovarajućim puferom, nakon čega se pomoću pipete ili kapaljke nanosi u otvor na test kaseti koji je predviđen za nanošenje uzorka. Nakon 10 - 15 minuta u zavisnosti od uputstva koje je dostavio proizvođač testa, rezultat se očitava u otvoru za očitavanje rezultata (slika 4).

Rezultati dobijeni takvim testom su u potpunosti kvalitativni. Pozitivan rezultat znači da je osoba bila u kontaktu sa virusom ili da je vakcinisana. U slučaju da osoba nije vakcinisana, nalaz antitela dokazuje samo činjenicu da je osoba bila zaražena i ni u kom slučaju ne znači da je ta osoba infektivna. Procena infektivnosti takve osobe se obavlja pažljivom analizom anamnestičkih i epidemioloških podataka i rezultata drugih laboratorijskih testova (rtRT-PCR, antigenski test). U najvećem broju slučajeva osoba nije infektivna 7 - 10 dana nakon pozitivnog rezultata nalaza antitela brzim testom za dokazivanje antitela.

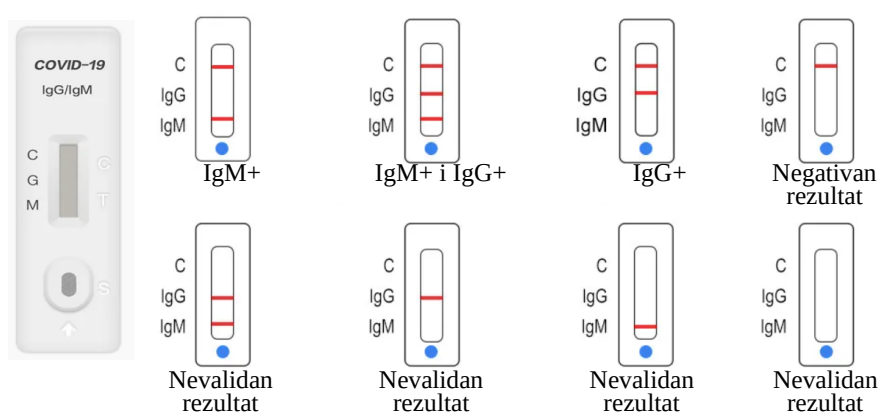

Slika 4. Brzi test za detekciju IgG i IgM antitela na antigene SARS-CoV-2 i mogući rezultati.

Enzimski imunotestovi za dokazivanje antitela

Testovi su namenjeni za dijagnostiku postojanja i kvantifikovanje humoralnog imunskog odgovora na antigene SARS-CoV-2. Baziraju se na dokazivanju postojanja različitih antitela (po pravilu IgM, IgG ili IgA) na pojedine antigene SARS-CoV-2. Po pravilu, krv se uzima iz vene, u epruvetu bez antikoagulansa ili sa aktivatorom koagulacije. Ukratko, uzorak seruma koji se testira meša se sa odgovarajućim puferom u razblaženju 1:50 do 1:200 (u zavisnosti od protokola proizvođača testa), nakon čega se pomoću pipete nanosi u bunarčić test ploče ili otvor na test kaseti koji je predviđen za nanošenje uzorka. Nakon inkubacija i ispiranja, u zavisnosti od uputstva koje je dostavio proizvođač testa, rezultat se očitava pomoću kolorimetra (slika 5), luminometra ili neke druge platforme za merenje, u zavisnosti od tipa testa.

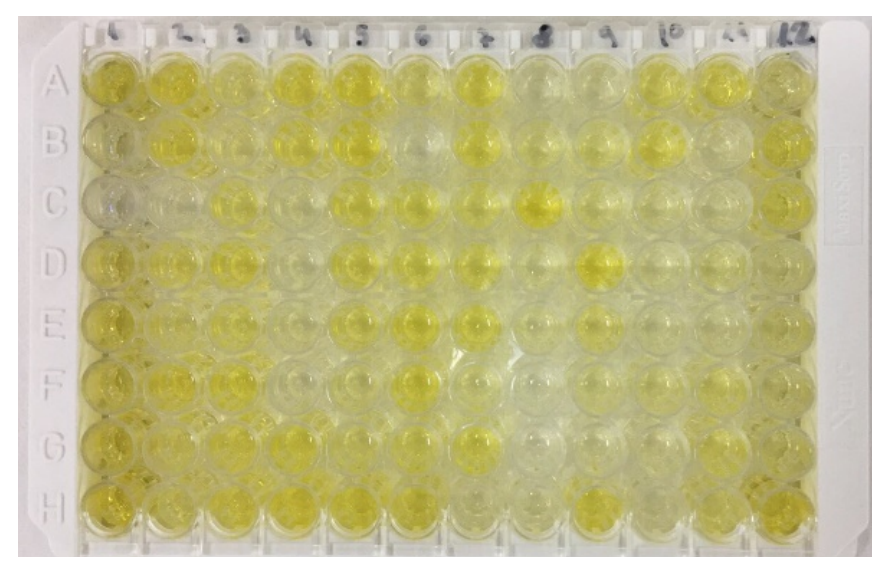

Slika 5. Detekcija antitela na SARS-CoV-2. Enzimski imunotest nakon zaustavljanja reakcije.

Rezultati dobijeni takvim testom mogu da budu u potpunosti kvantitativni. Pozitivan rezultat znači da je osoba bila u kontaktu sa virusom ili da je vakcinisana. Tumačenje se vrši analogno interpretaciji nalaza kod PoC testova za dokazivanje. Bitna prednost je mogućnost kvantifikacije i praćenja koncentracije antitela kroz vreme. Pri tome treba imati na umu da se, u tom slučaju, mogu porediti samo vrednosti serijskih uzoraka seruma koji su analizirani istim reagensima na istoj platformi i, poželjno, $\mathrm{u}$ isto vreme. To zahteva da se jednoj osobi krv uzima $\mathrm{u}$ 
više vremenskih tačaka, pri čemu je najmanji razmak između dve vremenske tačke deset dana (a kasnije to može da bude i više meseci), odvaja i zamrzava serum, a nakon prikupljanja svih planiranih uzoraka od jedne osobe svi uzorci u potrebnim razblaženjima (kako bi se obezbedilo da koncentracija antitela bude unutar opsega merenja) testiraju se zajedno. To je najsigurniji način za praćenje dinamike koncentracije antitela u krvi pacijenta, tj. za dokazivanje porasta koncentracije nakon vakcinacije ili infekcije i praćenje smanjenja koncentracije antitela po oporavku pacijenta. Poređenje i izvlačenje zaključka o dinamici sadržaja antitela iz uzoraka uzetih i testiranih na drugi način nije sasvim precizno.

\section{Testovi za dokazivanje neutrališućih antitela}

Pravi test za dokazivanje neutrališućih antitela podrazumevao bi inkubaciju vijabilnih SARS-CoV-2 viriona sa serumom pacijenta, a zatim inokulaciju te smese u kulturu ćelija permisivnih za SARS-CoV-2 i praćenje citopatogenog efekta u kulturi ćelija nakon više dana inkubacije (slika 6). Takav pristup nije bio moguć u našoj zemlji jer je za rad sa SARS-CoV-2 bila neophodna laboratorija 3. nivoa biološke bezbednosti, kakva u našoj državi ne postoji, a ni u okolnim državama ne postoji dovoljan broj takvih laboratorija. U međuvremenu, dizajnirani su virusi i pseudovirusi koji na svojoj površini imaju istaknut $S$ antigen SARS-CoV-2, koji im omogućava ulazak u ćelije permisivne za SARS-CoV-2 u koje izvorni nemodifikovani virus ne može da prodre. Rad sa takvim virusima može da se obavlja i u laboratorijama 2. nivoa biološke bezbednosti, kakve postoje u našoj državi. Pored toga, masovna vakcinacija među laboratorijskim osobljem omogućava bezbedan rad čak i sa vijabilnim SARS-CoV-2.
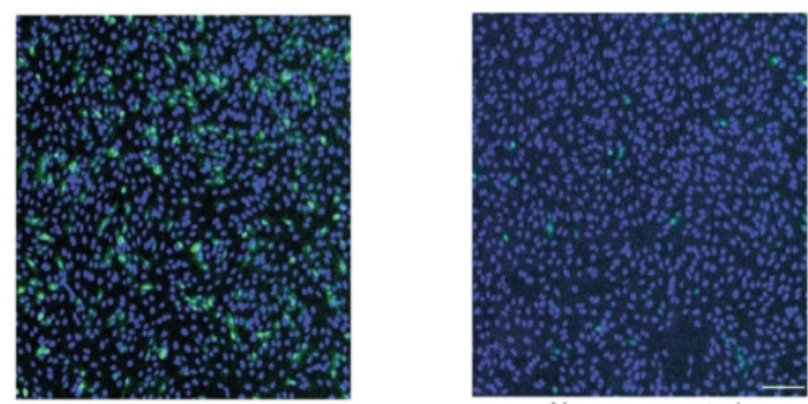

Slika 6. Slike kultura Vero CCL-81 ćelija inficiranih reporterskim virusom $m N G$ SARS-CoV-2 A. bez dodatka neutrališućih antitela i B. sa dodatkom neutrališućih antitela (6).

Mala procesivnost navedenih testova ne omogućava, međutim, širu primenu određivanja neutrališućih antitela pomenutim metodama. Takva situacija se prevazilazi uvođenjem testova inhibicije vezivanja rekombinantnog obeleženog $\mathrm{S}$ proteina za ACE molekul u prisustvu neutrališućih anti-S antitela $u$ formatu enzimskog imunotesta (slika 7). Takvi testovi mogu kvantitativno da odrede koncentraciju neutrališućih antitela i da se koriste za praćenje koncentracije neutrališućih antitela kroz vreme, pod uslovom da su uzorci krvi uzimani serijski i da je analiza vršena kako je opisano u prethodnom odeljku.

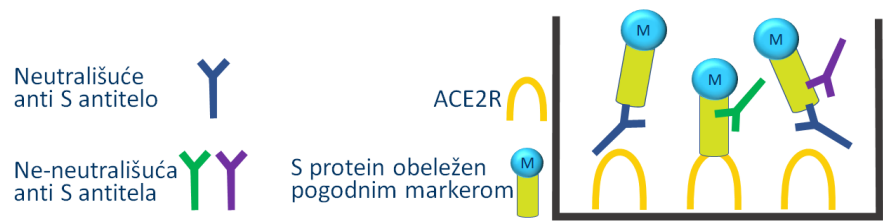

Slika 7. Shema testa za detekciju antitela koja inhibiraju vezivanje S proteina za ACE2 receptor.

Testovi za merenje funkcionalnog odgovora T-limfocita na stimulaciju antigenima

Testovi za merenje funkcionalnog odgovora T-limfocita na stimulaciju antigenom ne mogu da se izvode masovno, niti rezultati mogu da se očekuju brzo nakon uzorkovanja zbog osnovnih karakteristika samih testova. Zbog toga ostaju rezervisani za ograničeni broj osoba koje se testiraju u okviru naučnih studija ili mali broj pacijenata za koje bi ovakvo testiranje bilo od posebnog medicinskog značaja, kao što su pacijenti sa određenim urođenim ili stečenim (npr. jatrogenim) imunodeficijencijama. U našoj državi je moguće izvođenje testova baziranih na merenju sekrecije interferona gama ili blastne transformacije nakon stimulacije ćelija periferne krvi antigenima SARS-CoV-2.

\section{Quantiferon SARS-CoV-2}

Ovaj test je dostupan od proleća tekuće godine i zasnovan je na platformi široko primenjivanog testa za dijagnostiku latentne tuberkuloze. Ukratko, pacijentu se uzima uzorak krvi u epruvetu sa heparinom, a zatim se po $1 \mathrm{ml}$ heparinizovane krvi aseptično prenosi u dve epruvete sa peptidima SARS-CoV-2, u jednu epruvetu mitogenom (pozitivna kontrola testa) i jednu epruvetu bez ikakvog stimulusa (negativna kontrola testa). Epruvete se zatim inkubiraju 18 - $24 \mathrm{~h}$ na $37^{\circ} \mathrm{C}$, a zatim centrifugiraju kako bi se odvojila krvna plazma. Zatim se u plazmi određuje interferon gama enzimskim imunotestom (slika 8). Test je pozitivan ukoliko je razlika u koncentracijama interferona gama u plazmi iz makar jedne od dve epruvete sa peptidima SARS-CoV-2 veća od $0,15 \mathrm{IU} / \mathrm{ml}$ u odnosu na plazmu iz epruvete bez stimulusa. Kriterijum za validnost testa je da je u plazmi iz epruvete bez stimulusa koncentracija interferona gama manja od $8 \mathrm{IU} / \mathrm{ml}$, da je koncentracija interferona gama u plazmi iz epruvete sa mitogenom $25 \%$ viša od njegove koncentracije u plazmi iz epruvete bez stimulusa i najmanje $0,5 \mathrm{IU} / \mathrm{ml}$. Test je još uvek namenjen za istraživačke, ali ne i dijagnostičke svrhe (7).

\section{Test limfoblastne transformacije}

Test limfoblastne transformacije je zasnovan na činjenici da limfociti nakon stimulacije antigenom ulaze u ćelijsku deobu, pa je moguće merenje novosintetisane DNK nekom od radioaktivnih ili neradioaktivnih metoda ili je moguće prebrojavanje blasta koji su veći i nešto granulisaniji nego mirujući limfociti, što može da se detektuje protočnim citofluorimetrom (8). Ukratko, po $50 \mu \mathrm{l}$ heparinizovane periferne krvi, razblažene medijumom za kultivaciju, inkubira 
A

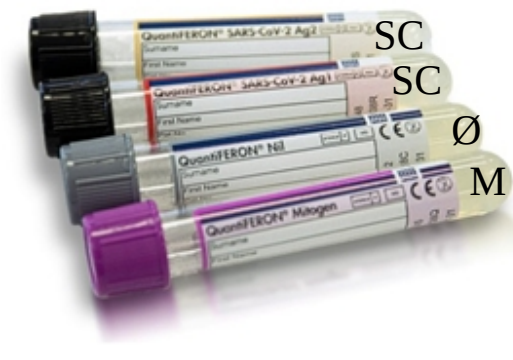

B

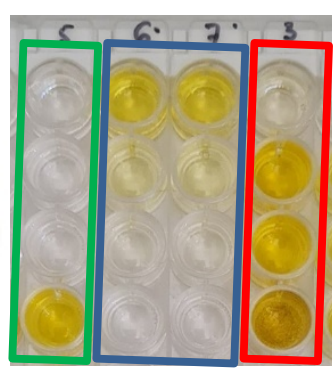

$\mathrm{C}$

\begin{tabular}{|c|c|c|c|c|c|c|c|c|c|c|}
\hline \multicolumn{4}{|c|}{ Negativan uzorak } & \multicolumn{3}{|c|}{ Standard } & \multicolumn{4}{|c|}{ Pozitivan uzorak } \\
\hline E & OD & $\begin{array}{c}{[\mathrm{C}]} \\
\mathrm{IU} / \mathrm{ml}\end{array}$ & $\begin{array}{l}\text { Stim. } \\
-\varnothing\end{array}$ & $\begin{array}{c}{[\mathrm{C}]} \\
\mathrm{IU} / \mathrm{ml}\end{array}$ & OD & OD & E & OD & $\begin{array}{c}{[\mathrm{C}]} \\
\mathrm{IU} / \mathrm{ml}\end{array}$ & $\begin{array}{l}\text { Stim } \\
\text { - }\end{array}$ \\
\hline$\varnothing$ & 0.01 & 0.04 & / & 4 & 1.14 & 1.06 & $\varnothing$ & 0.08 & 0.3 & / \\
\hline $\mathrm{SC} 1$ & 0.01 & 0.04 & 0 & 1 & 0.29 & 0.26 & $\mathrm{SC} 1$ & 2.98 & $>10$ & $>10$ \\
\hline $\mathrm{SC} 2$ & 0.01 & 0.04 & 0 & 0.25 & 0.07 & 0.06 & $\mathrm{SC} 2$ & 2.63 & 9.65 & 9.35 \\
\hline M & 2.46 & 9.02 & 8.98 & 0 & 0.01 & 0.01 & M & 3.97 & $>10$ & $>10$ \\
\hline
\end{tabular}

Slika 8. A. Epruvete za kvantiferon SARS-CoV-2. Epruvete (odozgo na dole) sadrže peptide SARS-CoV-2 koji stimulišu i CD8+ i CD4+ T-limfocite (SC2), peptide SARS-CoV-2 koji pretežno stimulišu CD4+ T-limfocite (SC1), ne sadrži stimulus (Ø) i sadrži mis togen (M). B. Stripovi sa negativnim uzorkom (uokvireno zelenom linijom, standardima (uokvireno plavom linijom) i pozitivnim uzorkom (uokvireno crvenom linijom). C. Tabela sa vrednostima intenziteta boje, koncentracijama interferona gama i vrednostima koncentracija interferona gama u epruvetama sa SC1, SC2 i mitogenom umanjenim za vrednost koncentracije interferona gama u epruveti bez stimulusa (Ø). E označava epruvetu, odnosno vrstu stimulacije; OD je optička gustina (intenzitet boje) tečnosti u bunarčiću; [C] je koncentracija interferona gama.

se sa antigenom, antigenima (nastavnici i saradnici Hemijskog fakulteta Univerziteta u Beogradu su uspeli da prečiste $\mathrm{S}$ i N antigene) ili peptidima SARS-CoV-2, mitogenom (pozitivna kontrola testa) i bez stimulacije (negativna kontrola testa) u polipropilenskim epruvetama 7 dana na $37^{\circ} \mathrm{C}$ i inkubatoru u atmosferi sa $5 \% \mathrm{CO}_{2}$. Nakon inkubacije aspirira se medijum (može da se iskoristi za određivanje citokina), a ćelije se boje fluorescentno obeleženim antitelima specifičnim za $C D 3, C D 4, C D 8$ i $C D 19$. Nakon bojenja, liziraju se eritrociti i zatim se uzorci analiziraju na protočnom citofluorimetru. Broj dvostruko pozitivnih ćelija $(C D 3+C D 4+, C D 3+C D 8+)$ i broj $C D 19+$ ćelija u limfoblastnom regionu odgovara brojevima aktiviranih pomoćničkih T-limfocita, citotoksičnih T-limfocita i B-limfocita (slika 9).
Saopštavanje rezultata i objavljivanje podataka

Na samom početku epidemije rezultati su ručno upisivani u laboratorijski protokol, a zatim su izdavani odštampani iz Word-a, potpisivani i pečatirani. Već krajem marta 2020. rezultati su se unosili u COVID-19 bazu podataka, ali pritisak za izdavanjem štampanih rezultata (potvrda) za pojedinačna lica nije jenjavao. Pored toga, iz zdravstvenih ustanova i zavoda za javno zdravlje zahtevane su i zbirne tabele sa rezultatima za sve uzorke poslate određenog dana. Takva praksa je preterano iscrpljivala osoblje koje je izdavalo rezultate u dijagnostičkim laboratorijama. Tokom aprila i maja 2020. Baza COVID-19 je usavršavana nekoliko puta, pa su se pojedina polja automatski popunjavala tokom

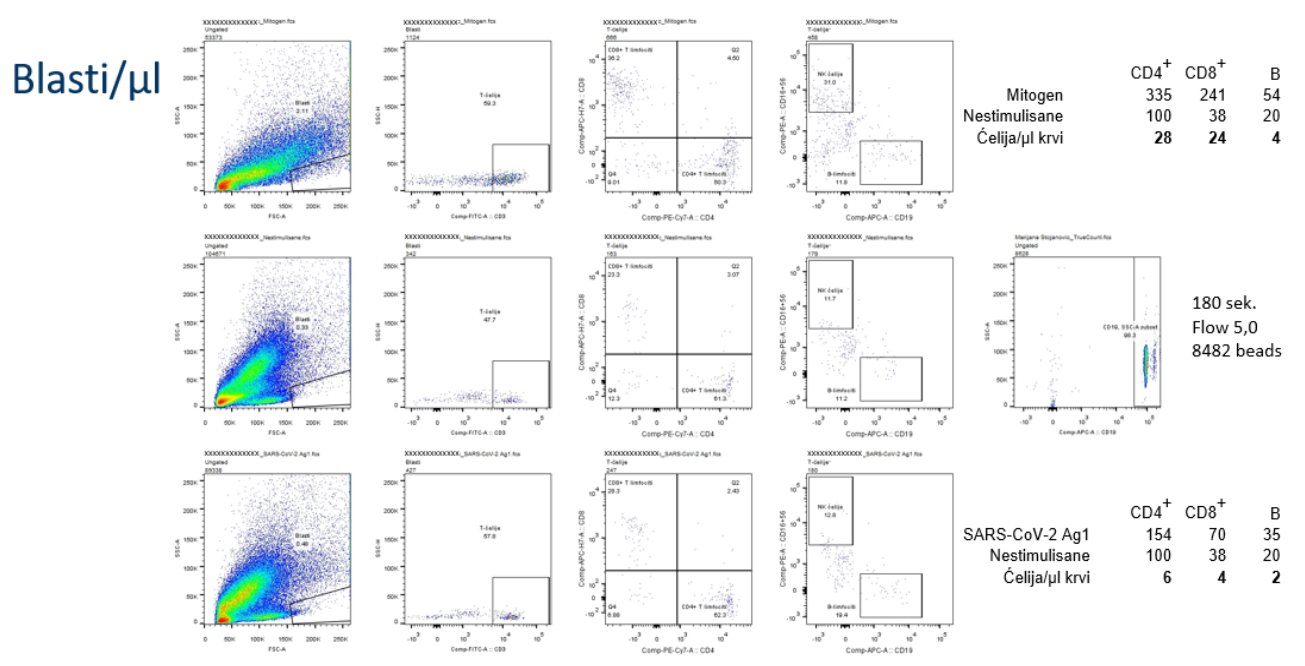

Slika 9. Test limfoblastne transformacije.

Rezultat se izdaje kao broj ćelija pojedine populacije limfocita u jedinici zapremine krvi (obično po $\mu$ l), a dobija se oduzimanjem broja ćelija određene populacije u limfoblastnom regionu iz epruvete sa nestimulisanim uzorkom od broja ćelija u limfoblastnom regionu iz epruveta nakon stimulacije, podeljeno sa zapreminom krvi iskorišćenom na analizu. Test je još uvek namenjen za istraživačke svrhe i još je dosta daleko od standardizacije za dijagnostiku. unošenja pojedinačnih rezultata, a omogućeno je i simultano unošenje većeg broja rezultata iz pripremljene Excel tabele. Paralelno, omogućeno je automatsko slanje rezultata pacijentima e-mail-om ukoliko su ostavljali $e$-mail adrese. Objavljivanje podataka nije bilo dovoljno informativno jer nije bilo jasno, makar na početku pandemije, koliko je pozitivnih testova rezultat prvog testiranja, a koliko rezultat retestiranja. Kasnije nije bilo jasno koliko je bilo testiranja PCR, a koliko antigenskim ili serološkim testovima. 
Baza COVID-19 je dosta unapređena od marta 2020. godine do danas, ali i dalje postoji dosta prostora za usavršavanje. Omogućeno je pretraživanje baze po određenom broju kriterijuma vezanih za lice, ali nije omogućeno filtriranje i pretraživanje po svim popunjenim poljima ili unetim vrednostima. Još uvek nisu ispunjeni FAIR principi (engl. Findability, Accessibility, Interoperability, and Reusability) (9). Jasno je da su vreme i resursi da se napravi takva baza podataka bili nedovoljni, ali je to nešto čemu treba da se stremi. Za svaki PCR rezultat bi bilo poželjno da postoje podaci kojim reagensima je obrađivan i amplifikovan i koje su bile Ct vrednosti IPC i virusnih gena. U slučaju enzimskih imunotestova trebalo bi da su dostupne optičke gustine razvijene boje. U idealnom slučaju, u bazu bi bili uneseni i metapodaci, kao što je izvorni fajl sa PCR mašine sa fotografijama ploče pre i nakon PCR. U slučaju enzimskog testa na fotografijama bi se videle oznake eksperimenta i nivoi i boje tečnosti. Takvi podaci bili bi linkovani sa uzorkom. Tada bi interpretacija rtRT-PCR i rezultata enzimskih imunotestova mogla da se obavlja i izvan laboratorije. Dodatno, korisno bi bilo geolociranje mesta boravišta i prebivališta pacijenta i mesta uzorkovanja i obrade uzoraka. Saopštenja za javnost bi trebalo reformatirati u delu koji se odnosi na laboratorijsko testiranje i jasno naznačiti: 1) broj laboratorijski testiranih; 2) broj osoba testiranih rtRT-PCR metodom; 2a) brojeve i procente pozitivnih testova; $2 \mathrm{~b}$ ) koliko je od tih testova bilo prvo testiranje neke osobe; $2 \mathrm{c}$ ) brojeve i procente pozitivnih koji su prvi put testirani; 3 ) broj seroloških testova; $3 a$ ) broj imunohromatografskih testova; $3 \mathrm{~b}$ ) broj enzimskih testova; $3 \mathrm{c}$ ) seroprevalenciju među testiranima tog dana; 3d) kumulativnu seroprevalenciju među testiranima; 4) broj imunohromatografskih testova za dokazivanje antigena; 4a) broj i procenat pozitivnih testova za dokazivanje antigena. Takva struktura podataka olakšala bi razumevanje ozbiljnosti situacije i ostavila manje mesta za zlonamerno komentarisanje.

Umesto zaključka:

Ђe je срећа, my je u несрећа

Ђе несрећа, mу и среће има

(Filip Višnjić, pesma Smrt Marka Kraljevića)

Iz toga sledi, vakcinišite se ukoliko to još uvek niste učinili.
4. Center for Disease Control and Prevention. Overview of Testing for SARS-CoV-2 (COVID-19) (Internet). Atlanta (USA). 2021. (cited 2021. Avg 3). Available from: https://www.cdc.gov/ coronavirus/2019-ncov/hcp/testing-overview.html.

5. Lai CC, Wang CY, Ko WC, Hsueh PR. In vitro diagnostics of coronavirus disease 2019: Technologies and application. Journal of microbiology, immunology, and infection = Wei mian yu gan ran za zhi. 2021; 54(2):164-74.

6. Muruato AE, Fontes-Garfias CR, Ren P, Garcia-Blanco MA, Menachery VD, Xie X, et al. A high-throughput neutralizing antibody assay for COVID-19 diagnosis and vaccine evaluation. Nature communications. 2020; 11(1):4059.

7. Qiaqen. QuantiFERON SARS-CoV-2 RUO. Hilden (Germany). 2021. (cited 2021. Jun 17). Available from: https://www.qiagen. $\mathrm{com} /$ us/products/diagnostics-and-clinical-research/infectiousdisease/quantiferon-sars-cov-2-ruo/?clear=true\#orderinginform ation.

8. Marits P, Wikström AC, Popadic D, Winqvist O, Thunberg S. Evaluation of $\mathrm{T}$ and $\mathrm{B}$ lymphocyte function in clinical practice using a flow cytometry based proliferation assay. Clinical immunology. 2014; 153(2):332-42.

9. Wikipedia. FAIR data (Internet). San Francisco (USA). 2021. (cited 2021. Avg 03). Available from: https://en.wikipedia.org/ wiki/FAIR_data.
Literatura

1. Worldometers. Coronavirus (Internet). 2021. (cited 2021. Jun 17). Available from: https://www.worldometers.info/coronavirus/.

2. Center for Disease Control and Prevention. COVID-19 Testing Overview (Internet). Atlanta (USA). 2021. (cited 2021. Jun 17). Available from: https://www.cdc.gov/coronavirus/2019-ncov/ symptoms-testing/testing.html.

3. Center for Disease Control and Prevention. Interim Guidelines for COVID-19 Antibody Testing (Internet). Atlanta (USA). 2021. (cited 2021. Avg 3). Available from: https://www.cdc.gov/ coronavirus/2019-ncov/lab/resources/antibody-tests-guidelines. html. 